\title{
Women's knowledge, attitude, and practice of breast self- examination in sub-Saharan Africa: a scoping review
}

\author{
Roseline H. Udoh', Mohammed Tahiru', Monica Ansu-Mensah', Vitalis Bawontuo 1,2,
} Frederick Inkum Danquah ${ }^{1}$ and Desmond Kuupiel ${ }^{2,3^{*}}$ (1)

\begin{abstract}
Background: Breast cancer (BC) is a non-communicable disease with increased morbidity and mortality. Early detection of $\mathrm{BC}$ contributes to prompt linkage to care and reduction of complications associated with $\mathrm{BC}$. Breast self-examination (BSE) is useful for detecting breast abnormalities particularly in settings with poor access to healthcare for clinical breast examination and mammography. Therefore, we mapped evidence on women's knowledge, attitude, and practice of BSE in sub-Sahara Africa (SSA).

Methods: We conducted a systematic scoping review using Arskey and O'Malleys' framework as a guide. We searched PubMed, Google Scholar, CINAHL, and Science Direct databases for relevant studies on women's knowledge, attitude and practice on BSE. Studies included in the review were from SSA countries as defined by the World Health Organization published from 2008 to May 2019. Two reviewers independently screened the articles at the abstract and full-text screening guided by inclusion and exclusion criteria. All relevant data were extracted, and a thematic analysis conducted. The themes were collated, and a narrative summary of the findings reported.
\end{abstract}

Results: Of the 264 potentially eligible articles identified from 595,144, only 21 met the inclusion criteria and were included for data extraction. These included studies were conducted in 7 countries of which 11 were conducted in Nigeria; two each in Ethiopia, Ghana, Cameroon, and Uganda; and one each in Kenya and Sudan. Of the 21 included studies, 18 studies reported evidence on BSE knowledge and practice; two on only knowledge; one on only practice only; and six presented evidence on women's attitude towards BSE. The study findings suggest varying knowledge levels on BSE among women in SSA countries. The study findings also suggest that BSE practice is still a challenge in SSA.

Conclusion: There is a paucity of published literature on women's knowledge, practice, and attitude of BSE in SSA. Hence, this study recommends further studies on knowledge, practice, and attitude of BSE, to identify contextual challenges and provide evidence-based solutions to improve women's knowledge, practice, and attitude of BSE in SSA.

Keywords: Breast cancer, Breast self-examination, Self-breast examination, Knowledge, Practice, Attitude, Women, Sub-Saharan Africa

\footnotetext{
* Correspondence: desmondkuupiel98@hotmail.com; KuupielD@ukzn.ac.za

${ }^{2}$ Research for Sustainable Development Consult, Sunyani, Ghana

${ }^{3}$ Department of Public Health Medicine, School of Nursing and Public Health, University of KwaZulu-Natal, Durban, South Africa

Full list of author information is available at the end of the article
}

(c) The Author(s). 2020 Open Access This article is licensed under a Creative Commons Attribution 4.0 International License, which permits use, sharing, adaptation, distribution and reproduction in any medium or format, as long as you give appropriate credit to the original author(s) and the source, provide a link to the Creative Commons licence, and indicate if changes were made. The images or other third party material in this article are included in the article's Creative Commons licence, unless indicated otherwise in a credit line to the material. If material is not included in the article's Creative Commons licence and your intended use is not permitted by statutory regulation or exceeds the permitted use, you will need to obtain permission directly from the copyright holder. To view a copy of this licence, visit http://creativecommons.org/licenses/by/4.0/. The Creative Commons Public Domain Dedication waiver (http://creativecommons.org/publicdomain/zero/1.0/) applies to the data made available in this article, unless otherwise stated in a credit line to the data. 


\section{Background}

Breast cancer (BC) has been described as the most commonly diagnosed cancer in women and the leading cause of cancer death globally [1]. In 2018, of the 8.6 million new cases of cancer globally, BC accounted for $24.2 \%$ of which $8.1 \%$ occurred in SSA. BC also accounted for nearly $15 \%$ of the 4.2 million mortality due to cancer worldwide with SSA accounting for $11.8 \%$ [1]. It is estimated that 1 in 8 women will develop BC over a lifetime and in the next decade 19.7 million new cases are expected globally by 2020 , and 10.6 million will occur in low-andmiddle-income countries (LMICs) [2, 3]. Similarly, it is projected that $43.1 \%$ of women will die due to $\mathrm{BC}$ worldwide and $36.8 \%$ will occur in LMICs by the end of 2020 [2].

These regional projections of $\mathrm{BC}$ incidence and mortality are worrying. Hence, demand immediate action to prevent and detect $\mathrm{BC}$ early through the different screening methods, as a mandate to help achieve the agenda for sustainable development goal (SDG) 3.4 by 2030 [4]. To facilitate early detection of BC, knowledge, attitude, and practice on the screening methods are essential. Although clinical breast examination and mammography are ideal for BC diagnosis, access to healthcare in most SSA countries may be a major challenge. Economic constraints in most SSA countries may impede the availability of mammography in the majority of the health facilities [5-7]. In addition, both clinical breast examination and mammography require expertise, specialized equipment, and a visit to the health facility [7]. However, breast self-examination (BSE) is a noninvasive procedure performed by the individual monthly to determine a normal breast and recognize any change on the breast for early medical care to be sought $[8,9]$. Evidence shows that nine out of the ten breast lumps are detected by the women themselves [9].

To this end, knowledge, attitude, and practice of BSE among women are essential. Knowledge of BSE involves having information on signs of $\mathrm{BC}$, BSE procedures and how to perform BSE [10-13]. Evidence shows that having knowledge of BSE has a positive impact on early detection of BC [14]. Knowledge of BSE may also influence the attitude and practice of BSE [13, 15]. Attitude is a settled way of thinking about BSE which includes acceptance that BSE is necessary, all women should perform it, ready to encourage other people to get information and to practice it and seeking early medical care with any abnormalities $[10,13,16]$. The practice of BSE involves the act of palpating one's breast monthly, just after menstruation, and the ability to detect abnormalities $[10,13,17]$. The practice of BSE makes the individual becomes familiar with the structure of her breast and be responsible for her health since the detection of any abnormality will necessitate seeking early medical care $[5,18]$. Despite this, to date, no study has methodically explored and described literature and identified research gaps on knowledge, attitude, and practice of BSE for future studies in SSA to the best of our knowledge. This current study, therefore, aimed to systematically map literature and describe the evidence on women's knowledge, attitude, and practice of BSE in SSA.

\section{Methods}

We employed Arksey and O'Malley's and Levac et al. recommendations $[19,20]$ to conduct a systematic scoping review focused on women's knowledge, attitude, and practice of BSE in SSA. The Arksey and O'Malley framework included in this study are as follows: identifying the research question, retrieving relevant studies, selection of studies, charting data, and collating, summarizing, reporting evidence. A detailed description of this study's methodology has been previously reported in the published protocol [21]. The preferred reporting items for systematic reviews and meta-Analyses extension for scoping reviews (PRISMA-ScR) checklist was followed to report this study (Supplementary file 1).

\section{Identifying the research question}

The main review question was: What evidence exists on women's knowledge, attitude, and practice of BSE in SSA?

The Sub review questions were as follows:

1. What is the evidence on the knowledge of BSE among women in SSA?

2. What is the evidence on the attitude toward BSE among women in SSA?

3. What is the evidence on BSE practice among women in SSA?

\section{Literature search}

An exhaustive search for potentially eligible articles was conducted in the following databases: PubMed, CINA HL, Google Scholar, and Science Direct to obtain relevant articles. The database search occurred in May 2019 using the following keywords: "women", "female" "selfbreast examination", "breast self-examination", "knowledge", "attitude", "practice”, "breast", “cancer", "breast cancer", "Africa", "sub sahara africa", south of the sahara", and "SSA"(Supplementary file 2). Boolean terms (AND/ OR) were used to separate the keywords. We also included Medical Subject Heading (MeSH) terms during the keywords search in the databases. To widen the scope of the search and capture the full range of literature on KAP of BSE, language and study design restrictions were removed during the databases search but the search date was limited from 2008 to the search date in 2019. We further search the reference list of all the included studies for eligible articles. 


\section{Study selection}

Guided by the eligibility criteria, RHU conducted database search and title screening. RHU and MT independently screened the abstracts and full articles in parallel. The discrepancies in the investigator's responses at the abstract screening stage were discussed by the review team until a consensus was reached. However, DK resolved the discrepancies between RHU and MT at the full-text screening stage. Then, Cohen's kappa coefficient, $\mathrm{\kappa}$ statistic between the reviewers was calculated after the full-text screening. This study included primary studies: conducted in SSA, published between 2008 to May 2019, reporting evidence among women 18 years and above, presenting evidence of women's knowledge, attitude, and practice of breast self-examination, and published in English. However, studies conducted in other countries outside SSA, articles reporting evidence among men, studies focused on cost-effective of BSE, articles presenting evidence on CBE as well as articles presenting evidence on a mammogram, and other review articles were excluded.

\section{Charting the data}

A thorough reading of the included studies for data extraction of bibliographic details, study title, aim/objectives, study design, target population, study setting, significant findings of interest were extracted. Other information like geographical location (urban or rural), country of study, sample size, and conclusion were also extracted to answer this review question. To ensure consistency and reliability of this study findings, RHU and DK independently extracted all relevant data from the included studies using a piloted form designed in Microsoft word.

\section{Collating, summarizing, and results}

All relevant data extracted were analysed thematically. The themes were collated, and a summary report of the finding presented narratively with a focus on this study outcome of interest (knowledge, attitude, and practice).

\section{Results}

In all, 365 articles met the eligibility criteria out of 595,144 at the title screening stage. Out of the 365 articles, 175 were duplicates hence, they were deleted prior to abstract screening. Subsequently, 143 and 26 articles were also excluded following abstract and full-text screening respectively (Fig. 1). There was a significant level of agreement between the investigators" responses at full article screening stage (Kappa statistic $=0.80, p<0.01$ ). Of the 26 fulltext articles excluded, eleven did not report on any of this study outcome of interest [22-32]; five studies were conducted outside this study setting [8, 33-36]; three reported on $\mathrm{CBE}$ and mammography [37-39]; three were review articles [40-42]; two studies reported on cost-effective of BSE $[5,7]$; one study reported evidence on male [43] and one full text could be accessed [44] despite several emails to the authors requesting for it. At the end of the study section process, 21 articles met the inclusion articles were included for data extraction.

\section{Characteristics of included studies}

Of the 21 included studies, one was a pre-experimental study [45], two were mixed methods studies [46, 47], and eighteen were descriptive cross-sectional surveys [48-65]. The majority $(11 / 21)$ of the included studies were conducted in Nigeria [46, 49-54, 57, 60, 62, 63] and the rest in Sudan [65], Kenya [64], Uganda [47, 59], Cameroon [55, 61], Ethiopia [45, 56], and Ghana [48, 58]. A total of 18 studies were conducted in urban settings [45-48, 50, 51, 53-62, 64, 65] while three were in a rural setting $[49,52,63]$. Table 1 presents a summary of the characteristics and findings of the included studies.

\section{Study findings}

Of the 21 studies, 18 studies reported evidence on knowledge and practice [45-52, 56-65] while 2 studies reported on knowledge only $[53,55]$, and one study on practice only [54]. Six of the included further reported evidence on the attitude of women towards BSE $[49,52$, $56,58,60,63]$.

\section{Knowledge of women on BSE}

Of the total 20 included studies that presented evidence on women's knowledge of BSE, eleven reported high (> 70\% of study participants) knowledge on BSE [46-48, 50, 58, 59, 61-65], two reported average BSE knowledge ( $\geq 50 \%$ of the study participants) $[49,60]$, and seven reported low $(<$ $50 \%$ study participant) BSE knowledge [45, 51-53, 55-57]. Of the eleven studies that revealed more than $70 \%$ of their study participants having knowledge on BSE, four were conducted in Nigeria $[46,50,62,63]$, two each in Ghana $[48,58]$ and Uganda $[47,59]$, one each in Cameroon [61], Kenya [64], Sudan [65].

In Cameroon, Nde et al. reported that $73.5 \%$ of their study participants had knowledge on BSE of which $37.3 \%$ knew BSE is performed monthly, 9\% knew how to perform it, and $88.6 \%$ knew BSE is important for early detection of BC [61]. In Sudan, Idris et al. study reported $86 \%$ BSE knowledge among the participants [65]. Kimani \& Muthumbi study in Kenya among female medical students in 2008 reported BSE 94.4\% BSE awareness [64].

Fondjo et al. study evaluated the knowledge among senior high school and tertiary students in Ghana and reported 90.9\% BSE knowledge among participants, of which $91.6 \%$ knew BSE as a tool for early detection of BC, 45.8\% knew BSE was done monthly, 21.1\% knew $\mathrm{BSE}$ is performed after menstruation, and the majority 

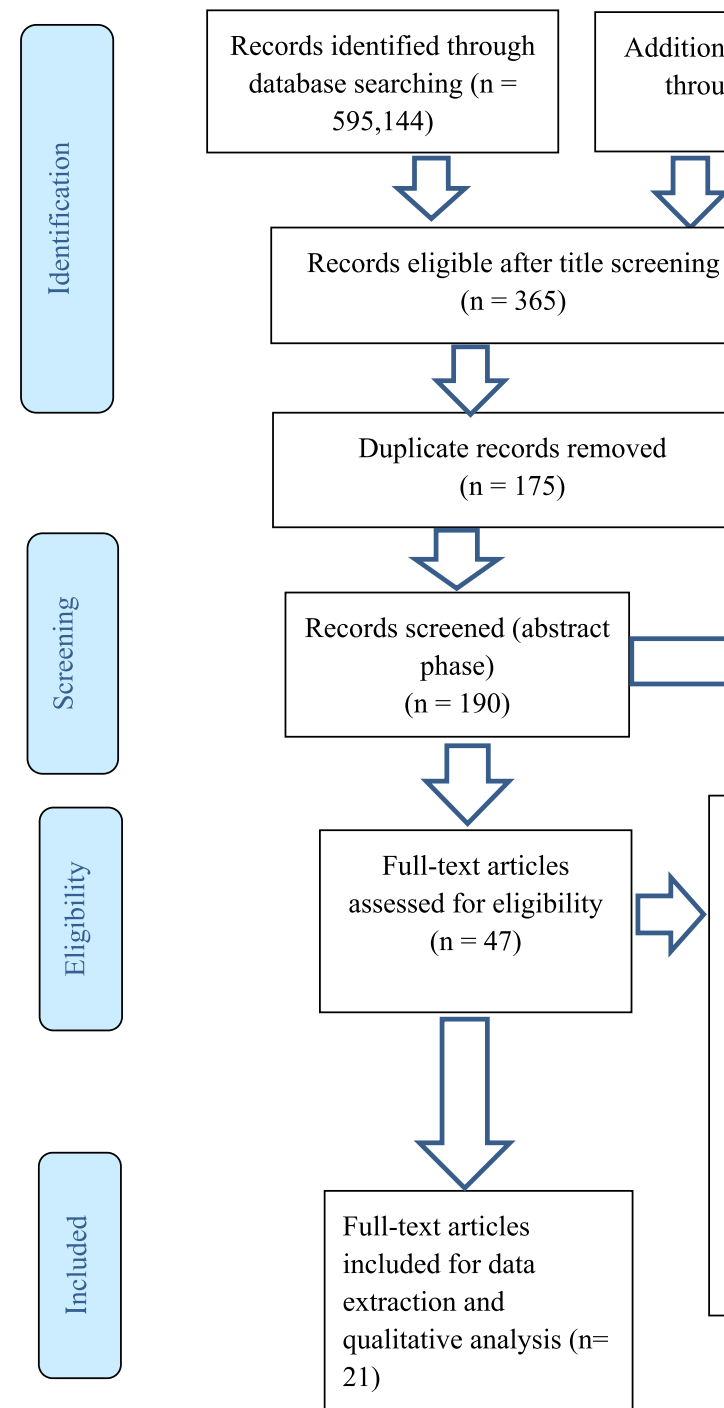

- Full-text articles excluded, with reasons $(n=26)$

* Review papers (3)

- No access to full text (1)

* Studies conducted elsewhere outside SSA (5)

* Cost effective of BSE (2)

* Clinical breast examination and mammography (3)

* Had male participants (1)

* Did not reported on any outcome of interest (11)

Fig. 1 PRISMA 2009 Flow Diagram

(63\%) knew the posture to assume during the performance of BSE [48]. Sarfo et al. also reported 95\% BSE knowledge among female nursing students and of which $60 \%$ of them knew BSE as a screening method for BC detection [58].

Two studies conducted in Uganda (Obaikol et al. \& Godfery et al.) revealed 81.5 and $76.5 \%$ BSE knowledge respectively among their participants $[47,59]$.

In Nigeria, a study reported $98.9 \%$ BSE knowledge in Owerri [62]. Casmir et al. reported that the participants who knew the age to begin BSE were 20.5 and $96.7 \%$ knew BSE was beneficial [62]. BSE knowledge of 85.1, 82 , and $74 \%$ was reported by Gwarzo et al.; Faronbi \&Abolade; and Sambo et al. among participants in their respective studies $[46,50,63]$. However, Faronbi \& Abolade study found that only $22 \%$ of the study participants understood the purpose for the performance of BSE, $12 \%$ knew BSE is done monthly, and 16\% knew the exact age to begin BSE [63]. Nonetheless, two studies involving rural women at a health facility and senior high school students in Nigeria respectively found 52.8 and $56.4 \%$ of the participants had access to information on BSE $[49,60]$. Isara \& Ojedokun, in 2011 reported that $56.4 \%$ of the participants had information on BSE, of which, 52.3\% knew BSE was a means of screening for $\mathrm{BC}, 12.5 \%$ knew the correct time to perform, and $18.8 \%$ knew BSE performance was a monthly required [60].

Of the seven studies that reported evidence of low BSE knowledge among their study participants [45, 51-53, 55-57], four were conducted in Nigeria [51-53, 57], two in Ethiopia [45, 56], and one in Cameroon [55]. Abere et al. assessed the effectiveness of planned teaching 
Table 1 Characteristics and study findings of included studies

\begin{tabular}{|c|c|c|c|c|c|c|}
\hline $\begin{array}{l}\text { Author and } \\
\text { date }\end{array}$ & Country & $\begin{array}{l}\text { Geographical } \\
\text { area }\end{array}$ & Study setting & Study design & $\begin{array}{l}\text { Study } \\
\text { population }\end{array}$ & $\begin{array}{l}\text { Significant } \\
\text { study findings }\end{array}$ \\
\hline $\begin{array}{l}\text { Abera et al, } \\
2017[45]\end{array}$ & Ethiopia & Urban & $\begin{array}{l}\text { University } \\
\text { campus }\end{array}$ & $\begin{array}{l}\text { pre- } \\
\text { experimental } \\
\text { study }\end{array}$ & $\begin{array}{l}1^{\text {st }} \\
\text { year midwifery } \\
\text { students }\end{array}$ & $\begin{array}{l}\text { Before intervention } 0 \% \text { never detect lump after } \\
\text { intervention } 77 \% \text { detected lump. }\end{array}$ \\
\hline $\begin{array}{l}\text { Agbonifoh, } \\
2016[54]\end{array}$ & Nigeria & Urban & $\begin{array}{l}\text { University } \\
\text { campus }\end{array}$ & $\begin{array}{l}\text { A descriptive } \\
\text { survey }\end{array}$ & $\begin{array}{l}\text { Female } \\
\text { students in the } \\
\text { tertiary } \\
\text { institution }\end{array}$ & $\begin{array}{l}\text { The course of study and knowledge of BSE significantly } \\
\text { influenced the practice of BSE, but parental and family } \\
\text { history of BC did not. }\end{array}$ \\
\hline $\begin{array}{l}\text { Casmir et } \\
\text { al, } 2015[62]\end{array}$ & Nigeria & Urban & $\begin{array}{l}\text { University } \\
\text { campus }\end{array}$ & $\begin{array}{l}\text { A descriptive } \\
\text { cross- } \\
\text { sectional } \\
\text { survey }\end{array}$ & $\begin{array}{l}\text { Female } \\
\text { undergraduate } \\
\text { students }\end{array}$ & $\begin{array}{l}\text { A statistically significant relationship between knowledge } \\
\text { of risk factors for BC, source of information on BSE, the } \\
\text { age of the respondents and practice of BSE. }\end{array}$ \\
\hline $\begin{array}{l}\text { Faronbi \& } \\
\text { Abolade, } \\
2012[63]\end{array}$ & Nigeria & Rural & $\begin{array}{l}\text { Senior High } \\
\text { School }\end{array}$ & $\begin{array}{l}\text { Descriptive } \\
\text { cross- } \\
\text { sectional } \\
\text { survey }\end{array}$ & $\begin{array}{l}\text { Female } \\
\text { secondary } \\
\text { school teachers }\end{array}$ & $22 \%$ understood BSE helped in early detection of BC. \\
\hline $\begin{array}{l}\text { Fondjo et } \\
\text { al, } 2018[48]\end{array}$ & Ghana & Urban & $\begin{array}{l}\text { Senior High } \\
\text { School/ } \\
\text { University } \\
\text { campus }\end{array}$ & $\begin{array}{l}\text { A cross- } \\
\text { sectional } \\
\text { study }\end{array}$ & $\begin{array}{l}\text { Female } \\
\text { students }\end{array}$ & $\begin{array}{l}\text { More tertiary students perform BSE than SHS students. } \\
76.3 \% \text { perform BSE because of the benefits. }\end{array}$ \\
\hline $\begin{array}{l}\text { Godfery et } \\
\text { al, } 2016[59]\end{array}$ & Uganda & Urban & $\begin{array}{l}\text { University } \\
\text { campus }\end{array}$ & $\begin{array}{l}\text { Cross- } \\
\text { sectional } \\
\text { study }\end{array}$ & $\begin{array}{l}\text { Female } \\
\text { students }\end{array}$ & $38 \%$ of those not practicing planned to practice. \\
\hline $\begin{array}{l}\text { Gwarzo et } \\
\text { al, } 2009[46]\end{array}$ & Nigeria & Urban & $\begin{array}{l}\text { University } \\
\text { campus }\end{array}$ & $\begin{array}{l}\text { Mix method } \\
\text { [quantitative/ } \\
\text { qualitative] }\end{array}$ & $\begin{array}{l}\text { Female } \\
\text { students }\end{array}$ & $\begin{array}{l}\text { Practice of BSE higher among those with a family history } \\
\text { of BC. Two students had detected a lump in their breast. }\end{array}$ \\
\hline $\begin{array}{l}\text { Idris et al, } \\
2013 \text { [65] }\end{array}$ & Sudan & Urban & $\begin{array}{l}\text { University } \\
\text { campus }\end{array}$ & $\begin{array}{l}\text { A descriptive } \\
\text { cross- } \\
\text { sectional } \\
\text { study }\end{array}$ & $\begin{array}{l}\text { Final year } \\
\text { female medical } \\
\text { students }\end{array}$ & $\begin{array}{l}46.5 \% \text { performed BSE correctly and } 44 \% \text { found lump by } \\
\text { performing BSE. }\end{array}$ \\
\hline $\begin{array}{l}\text { Isara \& } \\
\text { Ojedokun, } \\
2011[60]\end{array}$ & Nigeria & Urban & SHS campus & $\begin{array}{l}\text { A descriptive } \\
\text { cross- } \\
\text { sectional } \\
\text { study }\end{array}$ & $\begin{array}{l}\text { Female } \\
\text { students }\end{array}$ & $\begin{array}{l}\text { 31.4\% who had good knowledge of BSE had practiced } \\
\text { BSE. }\end{array}$ \\
\hline $\begin{array}{l}\text { Kimani \& } \\
\text { Muthumbi, } \\
2008[64]\end{array}$ & Kenya & Urban & $\begin{array}{l}\text { University } \\
\text { campus }\end{array}$ & $\begin{array}{l}\text { A cross- } \\
\text { sectional } \\
\text { descriptive } \\
\text { study }\end{array}$ & $\begin{array}{l}\text { Female } \\
\text { students }\end{array}$ & $\begin{array}{l}\text { No significant difference between the preclinical and } \\
\text { clinical in the practice of BSE. }\end{array}$ \\
\hline $\begin{array}{l}\text { Makanjuola } \\
\text { et al, } 2013 \\
{[52]}\end{array}$ & Nigeria & Rural & $\begin{array}{l}\text { Ala } \\
\text { community }\end{array}$ & $\begin{array}{l}\text { A descriptive } \\
\text { cross- } \\
\text { sectional } \\
\text { study }\end{array}$ & $\begin{array}{l}\text { Women living } \\
\text { in Ala } \\
\text { community }\end{array}$ & $34 \%$ recognize $\mathrm{BSE}$ as $\mathrm{BC}$ preventive measure. \\
\hline $\begin{array}{l}\text { Nde et al, } \\
2015 \text { [61] }\end{array}$ & Cameroon & Urban & $\begin{array}{l}\text { University } \\
\text { campus }\end{array}$ & $\begin{array}{l}\text { Cross- } \\
\text { sectional } \\
\text { descriptive } \\
\text { study }\end{array}$ & $\begin{array}{l}\text { Female } \\
\text { undergraduate } \\
\text { students }\end{array}$ & $\begin{array}{l}\text { Significant association between knowledge, attitude and } \\
\text { the tendency to practice BSE. Among those who } \\
\text { performed regularly } 22.2 \% \text { detected abnormal pains, } \\
\text { abnormal lump } 11.1 \% \text {, discharge of pus from nipple } \\
11.1 \% \text {, and abnormal size } 11.1 \%, 44.4 \% \text { other } \\
\text { abnormalities. }\end{array}$ \\
\hline $\begin{array}{l}\text { Obaikol et } \\
\text { al, } 2010[47]\end{array}$ & Uganda & Urban & $\begin{array}{l}\text { University } \\
\text { campus }\end{array}$ & Mix method & $\begin{array}{l}\text { Female } \\
\text { students }\end{array}$ & $\begin{array}{l}4.8 \% \text { found to have breast lumps, } 43.3 \% \text { knew BSE as a } \\
\text { screening method and } 42.1 \% \text { for diagnosis purposes. }\end{array}$ \\
\hline $\begin{array}{l}\text { Obaji et al, } \\
2013 \text { [51] }\end{array}$ & Nigeria & Urban & Market & $\begin{array}{l}\text { A cross- } \\
\text { sectional } \\
\text { descriptive } \\
\text { study }\end{array}$ & Women & $\begin{array}{l}\text { 38.9\% of the women admit BSE as a means of early } \\
\text { detection of BC, awareness of BSE is associated with the } \\
\text { level of education. }\end{array}$ \\
\hline $\begin{array}{l}\text { Oladimeji } \\
\text { et al, } 2015 \\
\text { [53] }\end{array}$ & Nigeria & Urban & Markets & $\begin{array}{l}\text { A descriptive } \\
\text { cross- } \\
\text { sectional } \\
\text { study }\end{array}$ & Market women & $\begin{array}{l}\text { Knowledge of the performance of BSE increased with } \\
\text { age and marital status. }\end{array}$ \\
\hline
\end{tabular}


Table 1 Characteristics and study findings of included studies (Continued)

\begin{tabular}{|c|c|c|c|c|c|c|}
\hline $\begin{array}{l}\text { Author and } \\
\text { date }\end{array}$ & Country & $\begin{array}{l}\text { Geographical } \\
\text { area }\end{array}$ & Study setting & Study design & $\begin{array}{l}\text { Study } \\
\text { population }\end{array}$ & $\begin{array}{l}\text { Significant } \\
\text { study findings }\end{array}$ \\
\hline $\begin{array}{l}\text { Olowokere } \\
\text { et al, } 2012 \\
\text { [49] }\end{array}$ & Nigeria & Rural & Health facility & $\begin{array}{l}\text { A descriptive } \\
\text { cross- } \\
\text { sectional } \\
\text { study }\end{array}$ & Rural women & $\begin{array}{l}\text { Majority of the women }[61.1 \% ; n=110] \text { who were not } \\
\text { practicing BSE likely to start practicing it. }\end{array}$ \\
\hline $\begin{array}{l}\text { Onwere et } \\
\text { al, } 2009 \text { [57] }\end{array}$ & Nigeria & Urban & $\begin{array}{l}\text { Antenatal } \\
\text { clinic }\end{array}$ & $\begin{array}{l}\text { A descriptive } \\
\text { cross- } \\
\text { sectional } \\
\text { study }\end{array}$ & Patients at ANC & BSE positively associated with attained educational level. \\
\hline $\begin{array}{l}\text { Sama et al, } \\
2017[55]\end{array}$ & Cameroon & Urban & $\begin{array}{l}\text { Teacher } \\
\text { Training } \\
\text { College }\end{array}$ & $\begin{array}{l}\text { Descriptive } \\
\text { cross- } \\
\text { sectional } \\
\text { study }\end{array}$ & $\begin{array}{l}\text { First cycle } \\
\text { female } \\
\text { undergraduate } \\
\text { students }\end{array}$ & $93 \%$ recognized the importance of BSE for their health. \\
\hline $\begin{array}{l}\text { Sambo et } \\
\text { al, } 2013[50]\end{array}$ & Nigeria & Urban & $\begin{array}{l}\text { University } \\
\text { campus }\end{array}$ & $\begin{array}{l}\text { A cross- } \\
\text { sectional } \\
\text { descriptive } \\
\text { stud }\end{array}$ & $\begin{array}{l}\text { Female } \\
\text { students }\end{array}$ & $\begin{array}{l}30.2 \% \text { mentioned breast lump as a feature of BC, no } \\
\text { significant association between knowledge and practice } \\
\text { of BSE and level of study. }\end{array}$ \\
\hline $\begin{array}{l}\text { Sarfo et al, } \\
2013 \text { [58] }\end{array}$ & Ghana & Urban & $\begin{array}{l}\text { University } \\
\text { campus }\end{array}$ & $\begin{array}{l}\text { A single case } \\
\text { study } \\
\text { approach }\end{array}$ & $\begin{array}{l}\text { Female nursing } \\
\text { students }\end{array}$ & $\begin{array}{l}\text { The majority had knowledge on BSE, cited BSE as a } \\
\text { method of BCS and that BSE was necessary }\end{array}$ \\
\hline $\begin{array}{l}\text { Segni et al, } \\
2016[56]\end{array}$ & Ethiopia & Urban & $\begin{array}{l}\text { University } \\
\text { campus }\end{array}$ & $\begin{array}{l}\text { A Cross- } \\
\text { sectional } \\
\text { study }\end{array}$ & $\begin{array}{l}\text { Female } \\
\text { students }\end{array}$ & $\begin{array}{l}44.2 \% \text { knew BSE is done monthly, } 53.8 \% \text { knew painless } \\
\text { nodules as a sign to diagnose BC. }\end{array}$ \\
\hline
\end{tabular}

program on knowledge and practice of BSE among firstyear female midwifery students in Hawassa Health Sciences College [45]. Their study showed that before intervention; $23 \%$ had heard of BSE, and 32\% knew BSE helps to detect lump early [45]. But after the teaching program, the study found that $100 \%$ had heard of BSE, and $96.7 \%$ knew BSE facilitates early detection of breast lumps [45]. Makanjuola et al. study also reported that $40 \%$ of the study participants had poor knowledge of BSE [52], while $48 \%$ of students were reported to have poor knowledge of BSE by Faronbi \& Abolade in their study [63]. Similarly, Isara \& Ojedokun study aimed at assessing the knowledge of senior high school students on BSE in Nigeria reported that $75.6 \%$ of the students had poor knowledge of BSE [60]. Whilst, Segni et al. study among University students found that $91.3 \%$ had poor knowledge of BSE [56]. These findings revealed varied knowledge levels on BSE among women in SSA countries, hence, requires further investigations.

\section{Attitude toward BSE}

Six studies out of the 21 included studies reported on the attitude of the participants toward BSE $[49,52,56,58,60$, 63]. The study by Isara \& Ojedokun in 2011 showed that the majority $(82.6 \%)$ of senior high school students in Nigeria had a positive attitude toward BSE [60]. Sarfo et al. study also reported that female nursing in Ghana had a positive attitude toward BSE [58]. Whereas in Ethiopia, $59.2 \%$ of the study participants were found to have a positive attitude toward BSE [56], and moderate attitude was reported by Nde et al. in Cameroon [61].
Faronbi \& Abolade; and Olowokere et al. in their studies in a rural setting in Nigeria reported poor attitude toward BSE $[49,63]$. This finding demonstrates limited literature on women's attitudes towards BSE.

\section{Practice of BSE}

Of the 21 studies, 19 reported evidence on the practice of BSE [45-52, 54, 56-65]. Four studies gave evidence of over $50 \%$ of participants who had practiced BSE [46, 50, $54,57]$ while 15 studies recorded evidence of low practice $[45,47-49,51,52,56,58-65]$. Agbonifoh, 2016 study among tertiary students in Edo state in Nigeria found out there was a high level of practice of BSE among participants [54]. Similar reports of high (78\%) practice of BSE was recorded by Onwere et al. in 2009 among antenatal patients in a teaching hospital in a South Eastern Nigeria [57]. Sambo et al. study in 2013 also reported that $55 \%$ of the undergraduate students in Northern Nigeria were practicing BSE [50]. Gwarzo et al. study in 2009 reported that $57 \%$ of the participants had ever practiced BSE 32.1\% [46].

Of the 15 with a low level of practices, six were conducted in Nigeria [49,51,52,60,62,63], two each in Ethiopia [45, 56], Ghana [48, 58], and Uganda [47, 59]; one each was conducted in Cameroon [61], Kenya [64] and Sudan [65]. Gwarzo et al. reported that only 19\% of their study participants were currently practicing BSE monthly [46]. Among the rural women in Ala community in Nigeria, $13 \%$ of the women practiced BSE as reported by Makanjuola et al. [52]. The study by Casmir et al.in 2015 also reported $32.5 \%$ of the participants practiced BSE 
[62], 31.4\% was also reported among senior secondary school students in Abuja Nigeria [60]. Again, in Nigeria, two studies found 12 and $11.7 \%$ of the study participants who practiced BSE $[49,63]$. The lowest percentage $(0.4 \%)$ of BSE practice was reported by Obaji et al. in their study in Nigeria involving market women in 2013 [51]. These findings show BSE practice remains a challenge in SSA and further studies are needed to investigate the barriers and facilitators of BSE practice.

\section{Discussion}

We conducted a scoping review to explore evidence on knowledge, attitude, and practice of BSE (KAP) among women in SSA. This study revealed evidence of women's KAP on BSE in seven SSA countries (Sudan, Nigeria, Ghana, Cameroon, Kenya, Ethiopia, and Uganda). The results generally demonstrate limited published research on knowledge, attitude and practice of BSE among women in SSA. The results also revealed varied knowledge levels on BSE among women in SSA countries. It further suggested that BSE practice remains a challenge in SSA.

We found evidence of women's KAP on BSE reported in seven SSA countries. This implies that we found no evidence in about 39 countries classified among SSA countries including the following: Angola, Benin, Botswana, Burkina Faso, Burundi, Cape Verde, Central African Republic, Chad, Comoros, Congo, Côte d'Ivoire, the Democratic Republic of the Congo, Equatorial Guinea, Eritrea, Gabon, Gambia, Guinea, Guinea-Bissau, Lesotho, Liberia, Madagascar, Malawi, Mali, Mauritania, Mauritius, Mozambique, Namibia, Niger, Rwanda, Sao Tome and Principe, Senegal, Seychelles, Sierra Leone, South Africa, Swaziland, Togo, United Republic of Tanzania, Zambia, and Zimbabwe although BC may be also be rising in these countries. This finding suggests limited research on knowledge, attitude, and practice of BSE among women in SSA. Similarly, Che Mut et al. systematic review BSE among female students also found limited studies [66]. This is worrying since BSE is a primary screening technique to detect breast abnormalities reporting for CBE or mammography.

We also found knowledge variations on BSE among women in SSA countries. It ranges from a low level to a higher level of knowledge with more of the low level of knowledge been reported. This, therefore, requires an intervention to increase the knowledge level of women in SSA. BSE has been reported as one of the screening methods for early detection of BC [5] therefore, in-depth knowledge, monthly practice and good attitude toward BSE are important for recognition of a normal breast and for detection of any abnormalities which is necessary for the control of morbidity and mortality associated with $\mathrm{BC}$ through early diagnosis of $\mathrm{BC}$ [16]. It further suggested that BSE practice remains a challenge in SSA. This challenge would require an intensive public campaign to help improve the practice of BSE in SSA.

\section{Implication for practice}

The review study included studies conducted in SSA where most of the clients with $\mathrm{BC}$ still present with endstage of $\mathrm{BC}$ [67], thus increasing the morbidity and mortality associated with BC in SSA [5, 68]. BSE is one of the screening methods for early detection of symptoms of $\mathrm{BC}$, even though $\mathrm{CBE}$ and mammograms are the most reliable methods. $\mathrm{CBE}$ is done at the health facility by trained personnel and mammogram also done at the facility but for clients 40 years and over. This implies that the women will have to go to a facility for any of these screening method and for mammogram at the age of 40 year, for a woman to go to the facility for screening except where mass screening are carried out, she need to have observed an abnormality which will be detected through BSE [69]. Our findings from the studies reviewed showed that some participants were able to detect lumps and other abnormalities in their breast from a regular practice of BSE [46, 47, 61, 65] It implies that planned tutorial on BSE will have a lot of impact especially among the health personnel's as reported in some of the studies $[45,54,65]$ and if the women are taught to practice BSE regularly, knowing what is abnormal in their breast, and any detection will necessitate seeking early medical care since they would have known the consequences of delays in reporting breast abnormalities $[51,58,60,65]$ This study's findings showed most of the participant indicated that BSE was a form of a screening method for early detection of abnormalities, therefore, an intensive public and institutional education is required on KAP of BSE with the aiming at early detection of abnormalities and subsequently seeking of early medical care, thereby reducing morbidity and mortality associated with $\mathrm{BC}$.

\section{Implication for research}

Our study shows limited published research on BSE in SSA. Most of the studies were conducted among tertiary students in an urban setting indicating a gap in literature among rural women. We hope our study will stimulate research studies on KAP of BSE among rural women in SSA who are more disadvantaged in accessing other $\mathrm{CBE}$ and mammography screening methods. We also recommend primary studies to assess KAP in those countries we found no evidence since the prevalence of $\mathrm{BC}$ is increasing in SSA. We further recommend primary research to assess the practice of BSE among midwives and nurses who had formal training on BSE during their course of study. We further recommend a systematic review and a meta-analysis to assess the impact of BSE knowledge and practice of BSE in SSA. Knowledge of 
the factors that influence the practice of BSE may be useful. Moreover, most of the included studies were descriptive cross-sectional surveys. This demonstrates the need for more interventional studies to identify innovative contextualised strategies or approaches to improving the practice of BSE among women in SSA.

\section{Strengths and limitations}

This scoping review probably is the first broad study to map evidence on KAP of BSE among women in SSA countries. The study showed a noteworthy gap in the literature on KAP of BSE among women in SSA countries. This study's methodology allowed the identification of eligible articles methodically, charting and analysing the outcomes [20]. Nonetheless, this study also has several limitations. This study sought to present recent evidence (within the last 10 year) hence, it included only articles published from 2008 onward. So, it possible some relevant articles published before 2008 were excluded. No quality appraisal was conducted as part of this study, but it is not essential due to the explorative nature of scoping reviews although we planned to assess the methodological quality of the included studies in the published protocol. We realized the number of included studies was few hence, reporting the risk of bias with these few studies may not be useful. Nonetheless, we will endeavour to perform the quality appraisal in the next phase of this study (a follow-up study full systematic review and meta-analysis). We also search for literature in only four databases, but it possible other relevant studies exist in other databases such as Scopus, Web of Science, and EMBASE that were not captured. We recommend future studies to conduct additional searches in those databases that were not captured by this study. It is possible researches on KAP of BSE existed under different terminologies that were not captured in the review. Nevertheless, we included MeSH terms to help address this. Furthermore, a meta-analysis using the quantitative data could generate more information but, this is not essential for scoping review studies. There may be several factors such as religious and cultural beliefs contributing to the KAP of BSE which were not captured by this study. We, therefore, recommend researches on the factors influencing KAP of BSE in SSA.

\section{Conclusion}

This study demonstrated that there is a paucity of published literature on women's knowledge, practice, and attitude of BSE in SSA. Most of the included studies reported low KAP of BSE. Considering the resource constraints in most health facilities in SSA countries, adequate knowledge and practice, as well as a good attitude towards BSE, is essential. Hence, this study recommends further studies on knowledge, practice, and attitude of BSE, to identify contextual challenges and provide evidence-based solutions to improve women's knowledge, practice, and attitude of BSE in SSA.

\section{Supplementary information}

Supplementary information accompanies this paper at https://doi.org/10. 1186/s13690-020-00452-9.

Additional file 1. Preferred Reporting Items for Systematic reviews and Meta-Analyses extension for Scoping Reviews (PRISMA-SCR) Checklist.

Additional file 2. Electronic search results for title screening.

\section{Abbreviations}

BC: Breast cancer; BSE: Breast self-examination; CBE: Clinical breastexamination; DALYs: Disability-adjusted life years; KAP: Knowledge, attitude, and practice; MMAT: Mixed method quality appraisal tool; LMICs: Low and middle-income countries; PCC: Population, content and context; PRISMASCR: Preferred reporting items for systematic reviews and meta-analyses modified for scoping reviews; SDG: Sustainable development goal; SHS: Senior high school; SS: Senior secondary; SSA: Sub-Sahara African; WHO: World health organization

\section{Acknowledgements}

We would like to express our gratitude Catholic University College of Ghana, Department of Health and Allied Sciences, University of KwaZulu-Natal, and Handmaids of the Holy Child Jesus congregation (Ghana Province) for making available the necessary resources for completion of this research.

\section{Authors' contributions}

$\mathrm{RHU}$ conceptualized and designed the study together with DK. RHU and MT contributed in the abstract, full article screening. RHU and MT contributed to the quality assessment of the included studies. RHU and DK contributed to the design and data extraction process as well as synthesis of data. RHU wrote the manuscript and MAM, BV, and DK critically reviewed it. All authors approved the final draft manuscript.

\section{Funding}

This study was funded by the Handmaids of the Holy Child Jesus congregation (Ghana Province). The funder played no role in the data collection, analysis, interpretation, and the preparation of the manuscript.

\section{Availability of data and materials}

The data supporting the conclusion of this paper are available through the detailed reference list. No original datasets are present since this is a review of the existing literature.

Ethics approval and consent to participate

A systematic scoping study uses existing literature, therefore ethical approval or consent of participation was not applicable.

\section{Consent for publication}

Not applicable.

\section{Competing interests}

The authors declare that they have no competing interests.

\section{Author details}

${ }^{1}$ Faculty of Health \& Allied Sciences, Catholic University College of GhanaFiapre, Sunyani, Ghana. ${ }^{2}$ Research for Sustainable Development Consult, Sunyani, Ghana. ${ }^{3}$ Department of Public Health Medicine, School of Nursing and Public Health, University of KwaZulu-Natal, Durban, South Africa.

Received: 2 April 2020 Accepted: 17 July 2020

Published online: 22 September 2020

\section{References}

1. Bray F, Ferlay J, Soerjomataram I, Siegel RL, Torre LA, Jemal A. Global cancer statistics 2018: GLOBOCAN estimates of incidence and mortality worldwide for 36 cancers in 185 countries. CA Cancer J Clin. 2018 Nov;68(6):394-424. 
2. Are C, Rajaram S, Are M, Raj H, Anderson BO, Chaluvarya Swamy R, Vijayakumar M, Song T, Pandey M, Edney JA, Cazap EL. A review of global cancer burden: trends, challenges, strategies, and a role for surgeons. J Surg Oncol. 2013;107(2):221-6.

3. Global Burden of Disease Cancer Collaboration, Fitzmaurice C, Abate D, et al. Global, Regional, and National Cancer Incidence, Mortality, Years of Life Lost, Years Lived With Disability, and Disability-Adjusted Life-Years for 29 Cancer Groups, 1990 to 2017: A Systematic Analysis for the Global Burden of Disease Study [published online ahead of print, 2019 Sep 27]. JAMA Oncol. 2019;5(12):1749-68. https://doi.org/10.1001/jamaoncol.2019.2996.

4. GA U. Transforming our world: the 2030 Agenda for Sustainable Development. New York: Division for Sustainable Development Goals; 2015.

5. Black E, Richmond R. Improving early detection of breast cancer in subSaharan Africa: why mammography may not be the way forward. Glob Health. 2019;15(1):3.

6. Bello TO, Olugbenga-Bello Al, Oguntola AS, Adeoti ML, Ojemakinde OM. Knowledge and practice of breast cancer screening among female nurses and lay women in Osogbo, Nigeria. West Afr J Med. 2011;30(4):296-300.

7. Adebusoye LA, Fatiregun AA, Ogunbode $O O$, Ogunbode AM. Breast examination as a cost-effective screening tool in a clinical practice setting in Ibadan, Nigeria. Afr J Prim Health Care Fam Med. 2013:5(1):1-7.

8. Wilke LG, Broadwater G, Rabiner S, Owens E, Yoon S, Ghate S, Scott V, Walsh R, Baker J, Soo MS, Ibarra-Drendall C. Breast self-examination: defining a cohort still in need. Am J Surg. 2009;198(4):575-9.

9. Agbo HA, Chingle MP, Envuladu EA, Zoakah Al. Breast Self Examination-A Necessary Preventive Tool: Knowledge and Practice among Students of College of Education Gindiri, Plateau State. Jos J Med. 2012;6(1):47-53.

10. Doshi D, Reddy BS, Kulkarni S, Karunakar P. Breast self-examination: Knowledge, attitude, and practice among female dental students in Hyderabad city, India. Indian J Palliat Care. 2012;18(1):68.

11. Yurdakos K, Gulhan YB, Unalan D, Ozturk A. Knowledge, attitudes and behaviour of women working in government hospitals regarding breast self examination. Asian Pac J Cancer Prev. 2013;14(8):4829-34.

12. Akpanekpo El. Knowledge, attitude and practice of breast self-examination (BSE) among female undergraduates in the University of Uyo, southern Nigeria. Evo J Public Health. 2017;2:6-11

13. Maggie A. Knowledge, attitudes and practices of women on breast cancer and breast self examination in kisaasi, kawempe division: Diss. Makerere University; 2015

14. Yakubu AA, Gadanya MA, Sheshe AA. Knowledge, attitude, and practice of breast self-examination among female nurses in Aminu Kano teaching hospital, Kano, Nigeria. Niger J Basic Clin Sci. 2014;11(2):85.

15. Hassan LM, Mahmoud N, Miller AB, Iraj H, Mohsen M, Majid J, Reza SM, Mojgan M. Evaluation of effect of self-examination and physical examination on breast cancer. Breast. 2015;24(4):487-90.

16. Pengpid S, Peltzer K. Knowledge, attitude and practice of breast selfexamination among female university students from 24 low, middle income and emerging economy countries. Asian Pac J Cancer Prev. 2014;15(20): 8637-40.

17. Anderson BO, Yip CH, Smith RA, Shyyan R, Sener SF, Eniu A, Carlson RW, Azavedo E, Harford J. Guideline implementation for breast healthcare in low-income and middle-income countries: Overview of the Breast Health Global Initiative Global Summit 2007. Cancer. 2008;113(S8):2221-43.

18. Nemenqani DM, Abdelmaqsoud SH, Al-Malki AH, Oraija AA, Al-Otaibi EM. Knowledge, attitude and practice of breast self examination and breast cancer among female medical students in Taif, Saudi Arabia. Open J Prev Med. 2014:2014

19. Arksey H, O'Malley L. Scoping studies: towards a methodological framework. Int J Soc Res Methodol. 2005;8(1):19-32.

20. Peters MD, Godfrey CM, Khalil H, Mclnerney P, Parker D, Soares CB. Guidance for conducting systematic scoping reviews. Int J Evid Based Healthc. 2015;13(3):141-6.

21. Udoh RH, Ansu-Mensah M, Tahiru M, Bawontuo V, Kuupiel D. Mapping evidence on women's knowledge and practice of breast self-examination in sub-Saharan Africa: a scoping review protocol. Syst Rev. 2020;9(1):1-4.

22. Abeje S, Seme A, Tibelt A. Factors associated with breast cancer screening awareness and practices of women in Addis Ababa, Ethiopia. BMC Womens Health. 2019;19(1):4.

23. Abay M, Tuke G, Zewdie E, Abraha TH, Grum T, Brhane E. Breast selfexamination practice and associated factors among women aged 20-70 years attending public health institutions of Adwa town, North Ethiopia BMC Res Notes. 2018;11(1):622.

24. Ossai EN, Azuogu BN, Ogaranya IO, Ogenyi Al, Enemor DO, Nwafor MA. Predictors of practice of breast self-examination: A study among female undergraduates of Ebonyi State University, Abakaliki, Nigeria. Niger J Clin Pract. 2019;22(3):361.

25. Birhane N, Mamo A, Girma E, Asfaw S. Predictors of breast self-examination among female teachers in Ethiopia using health belief model. Arch Public Health. 2015;73(1):39.

26. Getu MA, Kassaw MW, Tlaye KG, Gebrekiristos AF. Assessment of breast selfexamination practice and its associated factors among female undergraduate students in Addis Ababa University, Addis Ababa, Ethiopia, 2016. Breast Cancer Targets Ther. 2019;11:21.

27. Birhane K, Alemayehu M, Anawte B, Gebremariyam G, Daniel R, Addis S, Worke T, Mohammed A, Negash W. Practices of breast self-examination and associated factors among female debre berhan university students. Int J Breast Cancer. 2017;2017.

28. Azemfac K, Christie S, Carvalho MM, Nana T, Fonje AN, Halle-Ekane G, Dicker R, Chichom-Mefire A, Juillard C. A community-based assessment of knowledge and practice of breast self-examination and prevalence of breast disease in Southwest Cameroon. J Cancer Epidemiol. 2019;2019.

29. Moodley J, Cairncross L, Naiker T, Momberg M. Understanding pathways to breast cancer diagnosis among women in the Western Cape Province, South Africa: a qualitative study. BMJ Open. 2016;6(1):e009905.

30. Azage M, Abeje G, Mekonnen A. Assessment of factors associated with breast self-examination among health extension workers in West Gojjam Zone, Northwest Ethiopia. Int J Breast Cancer. 2013;2013.

31. Negeri EL, Heyi WD, Melka AS. Assessment of breast self-examination practice and associated factors among female health professionals in Western Ethiopia: A cross sectional study. Int J Med Med Sci. 2017;9(12):148-57.

32. Ogunbode AM, Fatiregun AA, Ogunbode OO. Breast self-examination practices in Nigerian women attending a tertiary outpatient clinic. Indian J Cancer. 2015:52(4):520

33. El Mhamdi S, Bouanene I, Mhirsi A, Sriha A, Salem KB, Soltani MS. Women's knowledge, attitudes and practice about breast cancer screening in the region of Monastir (Tunisia). Aust J Prim Health. 2013;19(1):68-73.

34. Al-Rifai RH, Loney T. Factors Associated with a Lack of Knowledge of Performing Breast Self-Examination and Unawareness of Cervical Cancer Screening Services: Evidence from the 2015 Egypt Health Issues Survey. Asian Pac J Cancer Prev. 2017;18(10):2763.

35. Tsangari $H$, Sharaa HM, Fouad NA, Petro W. A cross-cultural comparison between Cypriot and Egyptian women, on their perceptions of breast selfexamination as a screening method for breast cancer. World Appl Sci J. 2014;31(4):409-19.

36. Shahrbabaki PM, Farokhzadian J, Hasanabadi Z, Hojjatoleslami S. The evaluation of the educational plan of breast self-examination of women referring to health centers. Proc-Soc Behav Sci. 2012;31:913-7.

37. Akhigbe AO, Omuemu VO. Knowledge, attitudes and practice of breast cancer screening among female health workers in a Nigerian urban city. BMC Cancer. 2009:9(1):203.

38. Madubogwu Cl, Egwuonwu AO, Madubogwu NU, Njelita IA. Breast cancer screening practices amongst female tertiary health worker in Nnewi. J Cancer Res Ther. 2017;13(2):268

39. Opoku SY, Benwell M, Yarney J. Knowledge, attitudes, beliefs, behaviour and breast cancer screening practices in Ghana, West Africa. Pan Afr Med J. 2012;11(1).

40. Tetteh DA, Faulkner SL. Sociocultural factors and breast cancer in subSaharan Africa: implications for diagnosis and management. Womens Health. 2016;12(1):147-56.

41. Allen TL, Van Groningen BJ, Barksdale DJ, McCarthy R. The breast selfexamination controversy: what providers and patients should know. J Nurse Pract. 2010;6(6):444-51.

42. Maree J, Wright S, Lu X. Breast cancer risks and screening practices among women living in a resource poor community in Tshwane, South Africa. Breast J. 2013;19(4):453.

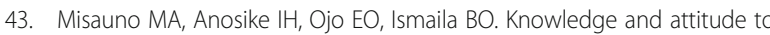
breast self-examination among a cohort of medical students in Nigeria. 2011. https://nairametrics.com/wp-content/uploads/2013/02/knowledgeand-attitude.pdf.

44. Amoran OE, Toyobo OO. Predictors of breast self-examination as cancer prevention practice among women of reproductive age-group in a rural town in Nigeria. Niger Med J. 2015;56(3):185. 
45. Abera H, Mengistu D, Bedaso A. Effectiveness of planned teaching intervention on knowledge and practice of breast self-examination among first year midwifery students. Plos one. 2017;12(9):e0184636.

46. Gwarzo UM, Sabitu K, Idris SH. Knowledge and practice of breast selfexamination among female undergraduate students. Ann Afr Med. 2009; $8(1)$.

47. Obaikol R, Galukande M, Fualal J. Knowledge and practice of breast self examination among female students in a sub Saharan African University. East Cent Afr J Surg. 2010;15(1):22-7.

48. Fondjo LA, Owusu-Afriyie O, Sakyi SA, Wiafe AA, Amankwaa B, Acheampong E, Ephraim RK, Owiredu WK. Comparative assessment of knowledge, attitudes, and practice of breast self-examination among female secondary and tertiary school students in Ghana. Int J Breast Cancer. 2018;2018.

49. Olowokere $A E$, Onibokun AC, Oluwatosin OA. Breast cancer knowledge and screening practices among women in selected rural communities of Nigeria. http://www.academicjournals.org/app/webroot/article/article13796 71914 Olowokereetal.pdf.

50. Sambo MN, Idris SH, Dahiru IL, Gobir AA. Knowledge and practice of selfbreast examination among female undergraduate students in a northern Nigeria university. J Med Biomed Res. 2013;12(2):62-8.

51. Obaji NC, Elom HA, Agwu UM, Nwigwe CG, Ezeonu PO, Umeora OU. Awareness and practice of breast self. Examination among market women in Abakaliki, South East Nigeria. Ann Med Health Sci Res. 2013;3(1):7-12.

52. Makanjuola OJ, Amoo PO, Ajibade BL, Makinde OY. Breast cancer: knowledge and practice of breast self examination among women in rural community of Ondo. 2013;8(1):32-7.

53. Oladimeji KE, Tsoka-Gwegweni JM, Igbodekwe FC, Twomey M, Akolo C, Balarabe HS, Atilola O, Jegede O, Oladimeji O. Knowledge and beliefs of breast self-examination and breast cancer among market women in Ibadan, South West, Nigeria. PloS one. 2015;10(11):e0140904.

54. Agbonifoh JA. Breast self examination practice among female students of tertiary institutions. J Educ Pract. 2016;7(12):11-8.

55. Sama CB, Dzekem B, Kehbila J, Ekabe CJ, Vofo B, Abua NL, Dingana TN, Angwafo F III. Awareness of breast cancer and breast self-examination among female undergraduate students in a higher teachers training college in Cameroon. Pan Afr Med J. 2017:28(1):164.

56. Segni MT, Tadesse DM, Amdemichael R, Demissie HF. Breast selfexamination: knowledge, attitude, and practice among female health science students at Adama Science and Technology University, Ethiopia. Gynecol Obstet (Sunnyvale). 2016:6(368):2161-0932.

57. Onwere S, Okoro O, Chigbu B, Aluka C, Kamanu C, Onwere A. Breast selfexamination as a method of early detection of breast cancer: knowledge and practice among antenatal clinic attendees in South Eastern Nigeria. Pak J Med Sci. 2009;25(1):122-5.

58. Sarfo LA, Awuah-Peasah D, Acheampong E, Asamoah F. Knowledge, attitude and practice of self-breast examination among female university students at Presbyterian University College, Ghana. Am J Res Commun. 2013;1(Suppl 11):395-404.

59. Godfrey K, Agatha T, Nankumbi J. Breast cancer knowledge and breast selfexamination practices among female university students in Kampala, Uganda: a descriptive study. Oman Med J. 2016;31(2):129.

60. Isara AR, Ojedokun Cl. Knowledge of breast cancer and practice of breast self examination among female senior secondary school students in Abuja, Nigeria. J Prev Med Hyg. 2011;52(4):186-90.

61. Nde FP, Assob JC, Kwenti TE, Njunda AL, Tainenbe TR. Knowledge, attitude and practice of breast self-examination among female undergraduate students in the University of Buea. BMC Res Notes. 2015;8(1):43.

62. Casmir EC, Anyalewechi NE, Onyeka IS, Agwu AC, Regina NC. Knowledge and practice of breast self-examination among female undergraduates in south-eastern Nigeria. Health. 2015;7(09):1134.

63. Faronbi JO, Abolade J. Breast self examination practices among female secondary school teachers in a rural community in Oyo State, Nigeria. http://www.scirp.org/fileOperation/downLoad.aspx?path=OJN201202 00013_19885538.pdf\&type=journal.

64. Kimani SM, Muthumbi E. Breast self examination and breast cancer: Knowledge and practice among female medical students in a Kenyan university. Ann Afr Surg. 2008;3(1).

65. Idris SA, Hamza AA, Hafiz MM, Ali ME, El Shallaly GE. Knowledge, attitude and practice of breast self examination among final years female medical students in Sudan. Breast Cancer. 2013:116:58-0.
66. Anis N, Che I, Hidayah N, Bakar A, Kamal I, Aishah S, et al. Breast selfexamination among female students: a systematic review. 2018;6(11):139-50.

67. Jedy-Agba E, McCormack V, Olaomi O, Badejo W, Yilkudi M, Yawe T, et al. Determinants of stage at diagnosis of breast cancer in Nigerian women: sociodemographic, breast cancer awareness, health care access and clinical factors. Cancer Causes Control. 2017;28(7).

68. Galukande M, Wabinga H, Mirembe F. Breast cancer survival experiences at a tertiary hospital in sub-Saharan Africa: A cohort study. World J Surg Oncol. 2015;13(1).

69. Smith RA, Caleffi M, Albert US, Chen TH, Duffy SW, Franceschi D, Nyström L, Global Summit Early Detection and Access to Care Panel. Breast cancer in limited-resource countries: early detection and access to care. Breast J. 2006; 12:S16-26.

\section{Publisher's Note}

Springer Nature remains neutral with regard to jurisdictional claims in published maps and institutional affiliations.
Ready to submit your research? Choose BMC and benefit from:

- fast, convenient online submission

- thorough peer review by experienced researchers in your field

- rapid publication on acceptance

- support for research data, including large and complex data types

- gold Open Access which fosters wider collaboration and increased citations

- maximum visibility for your research: over $100 \mathrm{M}$ website views per year

At BMC, research is always in progress.

Learn more biomedcentral.com/submissions 